Article

\title{
Clinical Significance of Serum NEDD9 Levels in Patients with Pancreatic Cancer
}

\author{
Cigdem Usul Afsar ${ }^{1, *}$, Mehmet Karabulut ${ }^{2}$, Senem Karabulut ${ }^{3}$, Safiye Tokgoz Ozal ${ }^{4}$, \\ Murat Cikot ${ }^{2}$, Murat Serilmez ${ }^{5}$ (i) and Faruk Tas ${ }^{3}$
}

1 Acıbadem Bakırkoy Hospital, Department of Internal Medicine and Medical Oncology, Medical Faculty, Acıbadem Mehmet Ali Aydınlar University, Zeytinlik Mah. Halit Ziya Usaklıgil Cad. No: 1, Bakırkoy, 34140 Istanbul, Turkey

2 Department of General Surgery, Bakırkoy Dr Sadi Konuk Education and Research Hospital, Health Sciences University, 34147 Istanbul, Turkey; mehmetkarabulut@hotmail.com (M.K.); mehmet_mac@hotmail.com (M.C.)

3 Department of Medical Oncology, Institute of Oncology, Istanbul University, 34452 Fatih/Istanbul, Turkey; drsenemkarabulut@gmail.com (S.K.); ftas@yahoo.com (F.T.)

4 Department of Radiology, Bakırkoy Dr Sadi Konuk Education and Research Hospital, Health Sciences University, 34147 Istanbul, Turkey; safiyeozal@gmail.com

5 Department of Basic Oncology, Institute of Oncology, Istanbul University, 34452 Istanbul, Turkey; serilmez55@hotmail.com

* Correspondence: cigdem.afsar@acibadem.edu.tr; Tel.: +90-212-4144067; Fax: +90-212-4144555

Received: 8 November 2018; Accepted: 3 December 2018; Published: 10 December 2018

\begin{abstract}
Introduction: Pancreatic cancer (PC) is a lethal malignancy. Various diagnostic, predictive, and prognostic biomarkers have been evaluated. This study was conducted to investigate the serum levels of neural precursor cell expressed developmentally downregulated protein 9 (NEDD9) in patients with PC and the relationship between tumor progression and known prognostic parameters. Materials and Methods: Serum samples were obtained on first admission before any treatment. Serum NEDD9 levels were determined using enzyme-linked immunosorbent assay (ELISA). Age- and sex-matched healthy controls were included in the analysis. Results: In a three year period, 32 patients with a pathologically-confirmed diagnosis of PC were enrolled in this study. The median age at diagnosis was 61 years, range 38 to 84 years; the majority of the patients in the group were men $(n=20,62.5 \%)$. The tumor was located in the head of pancreas in $21(65.6 \%)$ patients. Forty-one percent of 17 metastatic patients who received palliative CTx (chemotherapy) were CTx-responsive. The baseline serum NEDD9 levels were significantly higher in patients with PA than in the control group $(p=0.03)$. Median OS of the whole group were $27 \pm 7.3$ weeks. Alcohol intake, performance status, and LDH levels were found to be significant prognostic factors $(p=0.006, p<0.001$, and $p<0.001$, respectively). However, serum NEDD9 levels had no significantly effect on progression free survival (PFS) and overall survival (OS) ( $p=0.71$ and $p=0.58$, respectively). Conclusions: NEDD9 is identified as a secretory biomarker for PC but it has no prognostic role.
\end{abstract}

Keywords: NEDD9; pancreatic cancer; serum; diagnostic

\section{Introduction}

Pancreatic cancer (PC) is one of the most fatal cancers with an extremely poor prognosis even in its early stages. It is found to be metastatic at presentation in approximately $50 \%$ of cases $[1,2]$. It is the fourth leading cause of cancer-related death in the United States, and is second only to colorectal cancer as a cause of digestive cancer-related death [2]. Carcinoma of the exocrine pancreas is a genetic disease that is caused by inherited and acquired mutations in specific cancer-associated 
genes $[3,4]$. The patterns of genetic alterations identified in neoplasms of the pancreas are beginning to be integrated with tumor morphology and patient prognosis, and a new "molecular classification" of pancreatic neoplasia is slowly emerging [5]. Acquired genetic mutations may represent new targets for the development of sensitive screening tests for early diagnosis of pancreatic cancer, particularly before it becomes invasive [6,7].

Neural precursor cell expressed developmentally downregulated protein 9 (NEDD9) was initially identified by its developmentally regulated expression pattern in early embryonic, but not adult, mouse brain [8]. Overexpression of NEDD9 protein has now been strongly linked to poor prognosis in various types of cancers, as well as resistance to first-line chemotherapeutics [9-14]. There are few articles in the literature about the association of NEDD9 and PC [15-17]. It was shown that higher NEDD9 levels were significantly correlated with clinical staging, lymph node metastasis and histological differentiation and patients with a higher NEDD9 expression had a significantly shorter survival time than those patients with lower NEDD9 expression. NEDD9 could serve as an independent factor of poor prognosis in PC patients [15]. MicroRNA-145 suppresses cell proliferation, invasion and migration in PC cells by targeting NEDD9 [16] and baicalein, a flavone ingredient of Scutellaria baicalensis Georgi inhibits PC cell proliferation and invasion via suppression of NEDD9 expression and its downstream Akt and extracellular regulated kinase (ERK) signaling pathways [17]. The aim of this study was to investigate the expression and prognostic significance of NEDD9 in PC patients.

\section{Materials and Methods}

\subsection{Characteristics of the Patients and the Disease}

The serum samples of the 32 pancreatic cancer patients with histologically confirmed diseases who were referred to Istanbul University Institute of Oncology and Bakirkoy Dr Sadi Konuk Training and Research Hospital from February 2011 to October 2014 were obtained. The patients had not received chemotherapy and/or radiotherapy over the last 6 months. The stage of the disease was determined according to the American Joint Committee on Cancer (AJCC) and International Union against Cancer (UICC) staging systems. Prior to onset of the treatment, the patients had been processed through a detailed assessment including clinical history, physical examination, and a series of blood tests, such as tumor markers, lactate dehydrogenase, and complete blood count. Investigations were carried out following the rules of the Declaration of Helsinki of 1975, which was revised in 2013. Institutional review board of Istanbul University Institute of Oncology in 2014 with the number 299 was obtained before the study.

During a median follow-up of 16.5 weeks (range: 1-187 weeks) while 10 patients (31\%), experienced disease progression, 21 of the remaining patients (66\%) died. Median progression free survival (PFS) and overall survival (OS) of the whole group were $12.0 \pm 2.4$ weeks (95\% CI = 7-17 weeks) and $27.0 \pm 7.3$ weeks (95\% CI = 13-41 weeks), respectively. While 6-months OS rates were $51.1 \%(95 \% \mathrm{CI}=33.3-68.9)$. There were liver metastasis in $16(50 \%)$, abdominal implants in 3 patients, abdominal lymphadenopathy (LAP) in 3, lung in 2, and surrenal in 1 patient. Progression sites were liver in 6 patients, locally in 4 patients, and abdominal LAP in 1 patient.

\subsection{Statistical Analysis}

SPSS for Windows version 21.0 (SPSS Inc., Chicago, IL, USA) was employed for data analysis. Continuous variables were categorized using median values as cut-off point. Relationships and comparisons of several clinical/laboratory variables were evaluated via nonparametric tests. Mann-Whitney U-test was used to assess the serum levels between the subgroups. Overall survival was calculated from the date of first admission to the clinics to disease-related death or date of last contact with the patient or any family member. Progression-free survival was calculated from the date of admission to the date of first radiologic progression with/without elevated serum tumor marker. The Kaplan-Meier method was used for the estimation of survival distribution and differences 
in PFS and OS were assessed by the log-rank statistics. All statistical tests were carried out two-sided and a $p$-value $\leq 0.05$ was considered statistically significant.

\section{Results}

In a three years period, 32 patients with a pathologically confirmed diagnosis of PC were enrolled in this study. The baseline histopathological characteristics and the demographic characteristics of the patients are listed in Table 1. The median age at diagnosis was 61 years, range 38 to 84 years; the majority of the patients in the group were men $(n=20,62.5 \%)$. The tumor was located in the head of pancreas in $21(65.6 \%)$ patients. Forty-one percent of 17 metastatic patients who received palliative CTx were CTx-responsive. Surgery was performed in six (18.7\%) patients; three (9\%) patients underwent pancreaticoduodenectomy and three $(9 \%)$ patients had palliative surgery. Serum levels of laboratory parameters in patients were shown in Table 2.

Table 1. Characteristics of the patients and disease.

\begin{tabular}{|c|c|}
\hline Variables & $n$ \\
\hline No. of patients & 32 \\
\hline Age (years): Median (range) & $61(38-84)$ \\
\hline Gender: Male/Female & $20 / 12$ \\
\hline Smoking ${ }^{\text {a: }}$ Yes/No & $17 / 12$ \\
\hline Alcohol intake ${ }^{a}$ : Yes/No & $4 / 26$ \\
\hline Comorbidity ${ }^{\text {a: }}$ Yes/no & $20 / 10$ \\
\hline Weight loss ${ }^{\text {a: }}$ Yes/no & $16 / 6$ \\
\hline Jaundice: Yes/no & $7 / 25$ \\
\hline Performans status ${ }^{a}: 0 / 1 / 2 / 3$ & $6 / 13 / 6 / 6$ \\
\hline Surgery Type aa: Whipple surgery/palliative surgery & $3 / 3$ \\
\hline Tumor size $^{\text {a: }}<<$ Small $(<40 \mathrm{~mm}) / \geq$ large $(\geq 40 \mathrm{~mm})$ & $14 / 13$ \\
\hline Site of lesion: Head/Corpus-tail & $21 / 11$ \\
\hline $\begin{array}{l}\text { Response to chemotheraphy: Yes (PR + } \\
\text { SD)/no(PD)/unknown }\end{array}$ & $7 / 7 / 3$ \\
\hline Metastasis $(p)$ : Yes/no & $18 / 14$ \\
\hline
\end{tabular}

a Patients with unknown data concerning the variables are not included in the analysis. ${ }^{\text {aa }}$ In 14 patients with nonmetastatic. PR: partial response; SD: stable disease; PD: progressive disease

Table 2. Serum levels of laboratory parameters in patients.

\begin{tabular}{|c|c|}
\hline Variables & Values of $n(\%)$ \\
\hline \multicolumn{2}{|l|}{$\mathrm{WBC}^{\mathrm{a}}$} \\
\hline High $(>10,000) /$ normal $(<10,000)$ & $5 / 25$ \\
\hline \multicolumn{2}{|l|}{ Hemoglobin $^{\mathrm{a}}$} \\
\hline Low $(<12) /$ normal $(>12)$ & $11 / 19$ \\
\hline \multicolumn{2}{|l|}{ PLT $^{a}$} \\
\hline Low $(<150,000) /$ normal $(>150,000)$ & $4 / 26$ \\
\hline Lactate dehydrogenase $^{\mathrm{a}}$ & \\
\hline High $(>450 \mathrm{IU} / \mathrm{mL}) / \operatorname{normal}(<450 \mathrm{IU} / \mathrm{mL}$ & $3 / 23$ \\
\hline Albumin $^{\mathrm{a}}$ & \\
\hline Low $(<4 \mathrm{~g} / \mathrm{dL}) /$ normal $(>4 \mathrm{~g} / \mathrm{dL})$ & $20 / 9$ \\
\hline Carcinoembryonic antigen ${ }^{\mathrm{a}}$ & \\
\hline $\operatorname{High}(>5 \mathrm{ng} / \mathrm{mL}) / \operatorname{normal}(<5 \mathrm{ng} / \mathrm{mL})$ & $12 / 13$ \\
\hline CA19.9 $9^{a}$ & \\
\hline $\operatorname{High}(>38 \mathrm{U} / \mathrm{mL}) /$ normal $(<38 \mathrm{U} / \mathrm{mL})$ & $24 / 5$ \\
\hline
\end{tabular}

a Patients with unknown data concerning the variables are not included in the analysis. WBC: white blood cell; PLT: platelet; IU: international unit; CA: carbohydrate antigen. 
The levels of serum NEDD9 assays in patients with PA and healthy controls are shown in Table 3. The baseline serum NEDD9 levels were significantly higher in patients with PA than in the control group $(p=0.03)$ (Figure 1$)$.

Table 3. The values of serum marker levels in pancreatic cancer patients and healthy controls.

\begin{tabular}{cccccc}
\hline \multicolumn{3}{c}{ Patients $(\boldsymbol{n}=\mathbf{3 2})$} & \multicolumn{3}{c}{ Controls $(\boldsymbol{n = 2 0 )}$} \\
\hline Marker & Median & Range & Median & Range & $p$ \\
NEDD9 $(\mathrm{pg} / \mathrm{mL})$ & 1168.30 & $770.70-7523.11$ & 1048.21 & $659.24-1256.54$ & $0.03 *$ \\
\hline \multicolumn{4}{c}{$* p \leq 0.05}$.
\end{tabular}

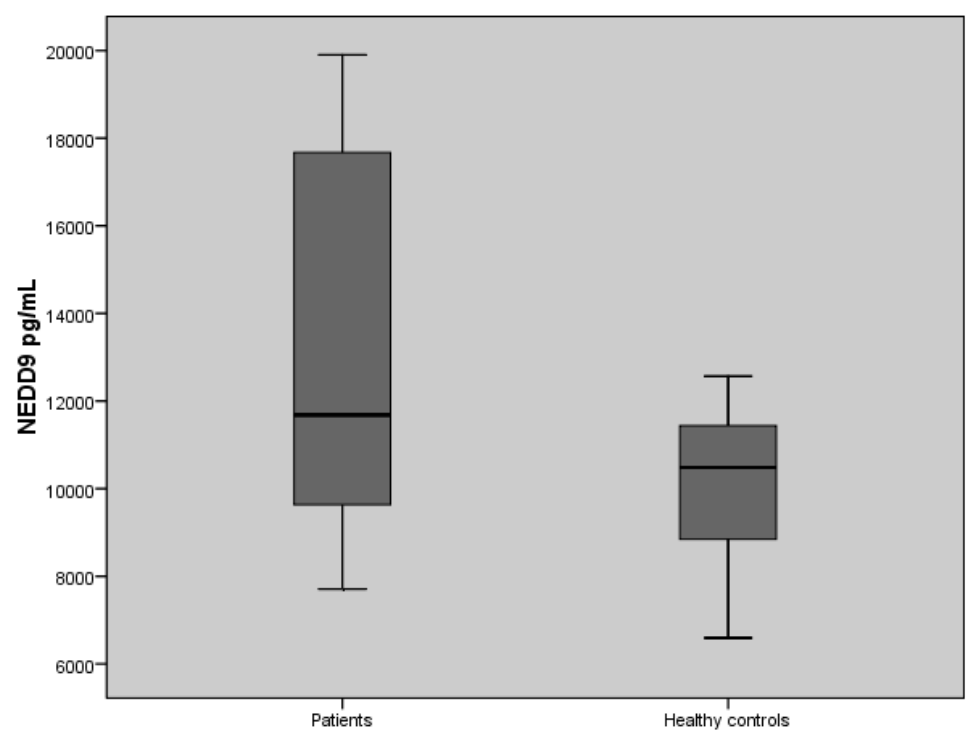

Figure 1. The values of serum neural precursor cell expressed developmentally downregulated protein 9 (NEDD9) assays in pancreatic cancer patients and controls $(p=0.03)$.

Table 4 shows the correlation between the serum levels of NEDD9 and clinicopathological factors. Median OS of the whole group were $27 \pm 7.3$ weeks. Alcohol intake, performance status, LDH levels were found to be significant prognostic factors $(p=0.006, p<0.001$, and $p<0.001$, respectively) (Table 5). However, serum NEDD9 levels had no significantly effect on PFS and OS ( $p=0.71$ and $p=0.58$, respectively) (Tables 5 and 6 and Figures 2 and 3).

Table 4. Comparisons of serum marker levels according to various clinical/laboratory parameters.

\begin{tabular}{ccc}
\hline Variables & Values of $\boldsymbol{n}$ & $\begin{array}{c}\text { NEDD9 (pg/mL) } \\
\text { Median (Range) }\end{array}$ \\
\hline Age patients $(p)$ & & 0.89 \\
Young $(<60)$ & 13 & $1169.93(880.57-3936.74)$ \\
Older $(>60)$ & 19 & $1166.67(770.7-7523.11)$ \\
Gender $(p)$ & & 0.64 \\
Male & 20 & $1180.56(770.70-7523.11)$ \\
Female & 12 & $1090.69(904.46-5525.55)$ \\
Smoking $(p)$ & 17 & 0.79 \\
Yes & 12 & $1130.72(770.70-7523.11)$ \\
No & & $108.30(904.46-6868.61)$ \\
Alcohol intake $(p)$ & 4 & 0.86 \\
Yes & 26 & $1148.70(770.70-7523.11)$ \\
No & & 0.36 \\
Comorbidity $(p)$ & 20 & $1180.56(821.66-6946.47)$ \\
Yes & 10 & $1030.31(770.70-7523.11)$ \\
No & &
\end{tabular}


Table 4. Cont

\begin{tabular}{|c|c|c|}
\hline Variables & Values of $n$ & $\begin{array}{l}\text { NEDD9 (pg/mL) } \\
\text { Median (Range) }\end{array}$ \\
\hline PS $(p)$ & & 0.9 \\
\hline Good (0-1) & 19 & $1169.93(770.70-7523.11)$ \\
\hline Worse (2-4) & 12 & $1148.70(880.57-6946.47)$ \\
\hline Weight loss $(p)$ & & 0.88 \\
\hline Yes & 16 & $1128.27(770.70-7523.11)$ \\
\hline No & 6 & $1365.28(821.66-6946.47)$ \\
\hline Jaundice $(p)$ & & 0.26 \\
\hline Yes & 7 & $1014.71(880.57-7523.11)$ \\
\hline No & 25 & 1191.18 (770.70-6946.47) \\
\hline Surgery $(p)$ & & 0.85 \\
\hline Yes & 6 & 1443.63 (821.66-1965.69) \\
\hline No & 26 & $1148.70(770.70-7523.11)$ \\
\hline Localization $(p)$ & & 0.86 \\
\hline Head & 21 & $1169.93(821.66-7523.11)$ \\
\hline Corpus-tail & 11 & $1125.82(770.70-6868.61)$ \\
\hline Tumor size $(p)$ & & 0.7 \\
\hline Small (<40 mm) & 14 & $1235.30(821.66-7523.11)$ \\
\hline Large $(\geq 40 \mathrm{~mm})$ & 13 & $1169.93(770.70-6868.61)$ \\
\hline Metastasis $(p)$ & & 0.43 \\
\hline Yes & 18 & 1084.97 (770.70-6946.47) \\
\hline No & 14 & $1433.01(821.66-7523.11)$ \\
\hline Liver metastasis $(p)$ & & 0.35 \\
\hline Yes & 16 & $1147.88(904.46-6946.47)$ \\
\hline No & 2 & $966.56(770.70-5525.55)$ \\
\hline Hemoglobin $(p)$ & & 0.95 \\
\hline Low & 11 & 1166.67 (952.23-6868.61) \\
\hline Normal & 19 & $1169.93(770.70-7523.11)$ \\
\hline $\mathrm{WBC}(p)$ & & 0.28 \\
\hline High & 5 & $1736.93(904.46-6868.61)$ \\
\hline Normal & 25 & $1130.72(770.70-7523.11)$ \\
\hline $\operatorname{PLT}(p)$ & & $0.04 *$ \\
\hline Low & 4 & 1247.55 (770.70-7523.11) \\
\hline Normal & 26 & $959.40(821.66-1130.72)$ \\
\hline Albumin $(p)$ & & 0.6 \\
\hline Low & 20 & 1247.55 (770.70-7523.11) \\
\hline Normal & 9 & 1066.99 (918.79-6868.61) \\
\hline Lactate dehydrogenase $(p)$ & & 0.32 \\
\hline High & 3 & $3936.74(952.23-6868.61)$ \\
\hline Normal & 23 & $1169.93(821.66-7523.11)$ \\
\hline Carcinoembryonic antigen $(p)$ & & 0.74 \\
\hline High & 13 & $1150.33(770.70-6946.47)$ \\
\hline Normal & 12 & $1191.18(821.66-6868.61)$ \\
\hline CA $19.9(p)$ & & $0.04^{*}$ \\
\hline High & 24 & 1965.69 (1066.99-6946.47) \\
\hline Normal & 5 & $1148.70(770.70-6868.61)$ \\
\hline Response to chemotherapy $(p)$ & & 0.85 \\
\hline Yes $(P R+S D)$ & 7 & 1166.67 (918.79-1990.20) \\
\hline No (PD) & 7 & $1044.12(821.66-5525.55)$ \\
\hline
\end{tabular}

Table 5. Univariate analyses of serum marker progression-free survival.

\begin{tabular}{cccc}
\hline Parameters & $\boldsymbol{N}$ of Events/Total $\boldsymbol{N}$ & $\begin{array}{c}\text { Survival (Weeks) } \\
\text { Median }( \pm \mathbf{S D})\end{array}$ & $\boldsymbol{p}$ \\
\hline $\begin{array}{c}\text { All patients } \\
\text { NEDD9 }\end{array}$ & $10 / 32$ & $12(2.4)$ & \\
<Median & $5 / 16$ & $13.0(3.3)$ & \\
> Median & $5 / 16$ & $12.0(4.4)$ & 0.71 \\
\hline
\end{tabular}


Table 6. Univariate analyses of overall survival.

\begin{tabular}{|c|c|c|c|c|}
\hline Parameters & $\mathrm{N}$ of Events/Total $\mathrm{N}$ & $\begin{array}{l}\text { Survival (Weeks) } \\
\text { Median }( \pm \text { SD) }\end{array}$ & $\begin{array}{c}\text { 6-Month Survival } \\
(\%)( \pm \text { SD) }\end{array}$ & $p$ \\
\hline All patients & $21 / 32$ & $27.0(7.3)$ & $51.1(9.1)$ & \\
\hline \multicolumn{5}{|l|}{ Age patients } \\
\hline Young $(<60)$ & $9 / 13$ & $31.0(12.3)$ & $68.4(13.1)$ & \multirow[t]{2}{*}{0.33} \\
\hline Older $(>60)$ & $12 / 19$ & $16.0(4.1)$ & $39.7(11.5)$ & \\
\hline \multicolumn{5}{|l|}{ Gender } \\
\hline Male & $11 / 20$ & $44.0(23.5)$ & $52.5(11.6)$ & \multirow[t]{2}{*}{0.21} \\
\hline Female & $10 / 12$ & $17.0(13.9)$ & $50.0(14.4)$ & \\
\hline \multicolumn{5}{|l|}{ Smoking } \\
\hline Yes & $11 / 17$ & $17.0(11.5)$ & $46.3(15.0)$ & \multirow[t]{2}{*}{0.35} \\
\hline No & $8 / 12$ & $39.0(20.3)$ & $57.8(12.2)$ & \\
\hline \multicolumn{5}{|l|}{ Alcohol intake } \\
\hline Yes & $3 / 4$ & $1.0(\mathrm{NR})$ & NR & \multirow[t]{2}{*}{$0.006^{*}$} \\
\hline No & $16 / 26$ & $31.0(9.5)$ & $59.2(10.0)$ & \\
\hline \multicolumn{5}{|l|}{ Comorbidity } \\
\hline Yes & $13 / 20$ & $17.0(12.2)$ & $48.2(11.4)$ & \multirow[t]{2}{*}{0.53} \\
\hline No & $6 / 10$ & $31.0(9.6)$ & $68.6(15.1)$ & \\
\hline \multicolumn{5}{|l|}{$\begin{array}{l}\text { INO } \\
P\end{array}$} \\
\hline Good (0-1) & $8 / 19$ & $44.0(8.6)$ & $71.6(10.8)$ & \multirow[t]{2}{*}{$<0.001$ * } \\
\hline Worse (2-4) & $12 / 12$ & $7.0(4.3)$ & $25.0(12.5)$ & \\
\hline \multicolumn{5}{|l|}{ Weight loss } \\
\hline Yes & $13 / 16$ & $11.0(1.8)$ & 34.7 (12.3) & \multirow[t]{2}{*}{0.11} \\
\hline No & $2 / 6$ & $39.0(27.7)$ & $83.3(15.2)$ & \\
\hline \multicolumn{5}{|l|}{ Jaundice } \\
\hline Yes & $7 / 7$ & $11.0(9.2)$ & $28.6(17.1)$ & \multirow[t]{2}{*}{0.09} \\
\hline No & $14 / 25$ & $31.0(8.4)$ & $57.8(10.2)$ & \\
\hline \multicolumn{5}{|l|}{ Surgery } \\
\hline Yes & $4 / 6$ & $27.0(7.4)$ & $51.6(10.1)$ & 0.78 \\
\hline No & $17 / 26$ & $15.0(16.7)$ & $50.0(20.4)$ & \\
\hline Localization & & & & \\
\hline Head & $13 / 21$ & $27.0(10.0)$ & $53.6(11.4)$ & 0.2 \\
\hline Corpus-tail & $8 / 11$ & $12.0(7.8)$ & $45.5(15.0)$ & \\
\hline T size & & & & \\
\hline Small $(<40 \mathrm{~mm})$ & $9 / 14$ & $31.0(9.3)$ & $64.3(12.8)$ & 0.28 \\
\hline Large (>40 mm) & $9 / 13$ & $12.0(1.7)$ & $34.6(13.8)$ & \\
\hline Metastasis & & & & \\
\hline Yes & $12 / 18$ & $12.0(6.0)$ & $40.7(12.3)$ & 0.12 \\
\hline No & $9 / 14$ & $31.0(11.4)$ & $64.3(12.8)$ & \\
\hline Liver metastasis & & & & \\
\hline Yes & $11 / 16$ & $12.0(5.6)$ & $39.1(13.1)$ & 0.31 \\
\hline No & $2 / 2$ & $17.0(12.3)$ & NR & \\
\hline Hemoglobin & & & & \\
\hline Low & $9 / 11$ & $15.0(5.1)$ & $36.4(14.5)$ & 0.06 \\
\hline Normal & $10 / 19$ & $31.0(11.6)$ & $65.6(11.4)$ & \\
\hline WBC & & & & \\
\hline High & $3 / 5$ & $11.0(3.0)$ & NR & 0.36 \\
\hline Normal & $16 / 25$ & $31.0(13.4)$ & $56.0(9.9)$ & \\
\hline PLT & & & & \\
\hline Low & $2 / 4$ & 57.0 (NR) & NR & 0.6 \\
\hline Normal & $17 / 26$ & $27.0(8.0)$ & $51.0(10.0)$ & \\
\hline Albumin & & & & \\
\hline Low & $14 / 20$ & $17.0(7.9)$ & $45.7(11.8)$ & 0.07 \\
\hline Normal & $4 / 9$ & 39.0 (NR) & 77.8 (13.9) & \\
\hline Lactate dehydrogen & & & & \\
\hline High & $3 / 3$ & $7.0(0.0)$ & NR & $<0.001$ * \\
\hline Normal & $13 / 23$ & $39.0(7.3)$ & $68.3(9.9)$ & \\
\hline Carcinoembryonic ant & & & & \\
\hline High & $10 / 13$ & $12.0(3.2)$ & $37.5(14.7)$ & 0.29 \\
\hline Normal & $8 / 12$ & $31.0(5.8)$ & $61.5(13.5)$ & \\
\hline
\end{tabular}


Table 6. Cont.

\begin{tabular}{ccccc}
\hline Parameters & N of Events/Total N & $\begin{array}{c}\text { Survival (Weeks) } \\
\text { Median }( \pm \text { SD) }\end{array}$ & $\begin{array}{c}\text { 6-Month Survival } \\
(\%)( \pm \text { SD) }\end{array}$ & $p$ \\
\hline CA 19 & $17 / 24$ & $27.0(7.4)$ & $51.6(10.6)$ & 0.13 \\
High & NR & NR & \\
Normal & $2 / 5$ & $31.0(2.6)$ & $71.4(17.1)$ & 0.25 \\
$\begin{array}{c}\text { Response to chemotherapy } \\
\text { Yes (PR + SD) }\end{array}$ & $4 / 7$ & $39.0(2.8)$ & $57.1(18.7)$ & \\
No (PD) & $5 / 7$ & & & \\
NEDD9 & & $27.0(14.0)$ & $56.3(12.4)$ & 0.58 \\
<Median & $10 / 16$ & $16.0(4.4)$ & $45.0(13.3)$ &
\end{tabular}

\section{Survival Functions}

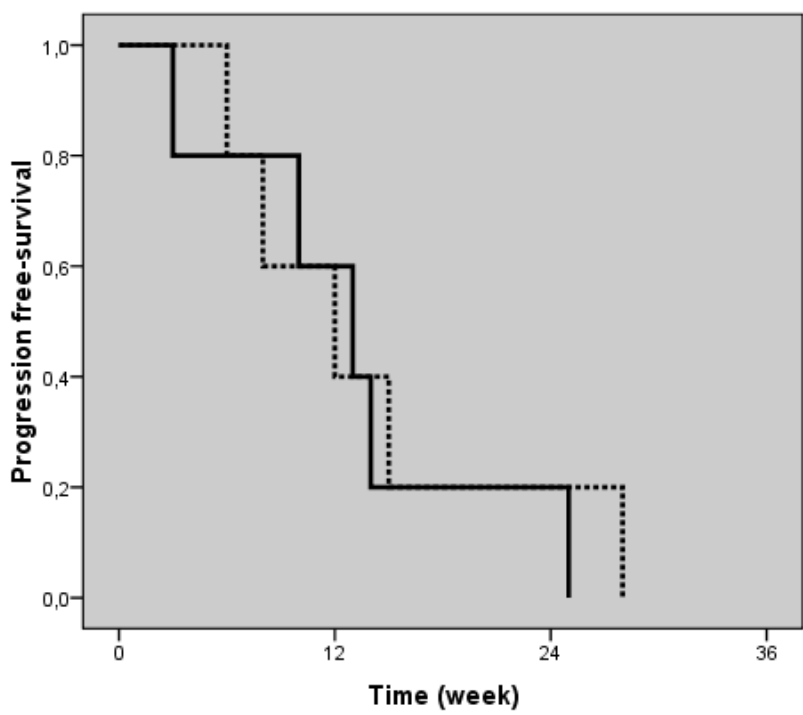

NEDD9

$\rightarrow$ MMEDIAN

Figure 2. Progression-free survival curves in pancreatic cancer patients according to serum NEDD9 levels $(p=0.71)$.

\section{Survival Functions}

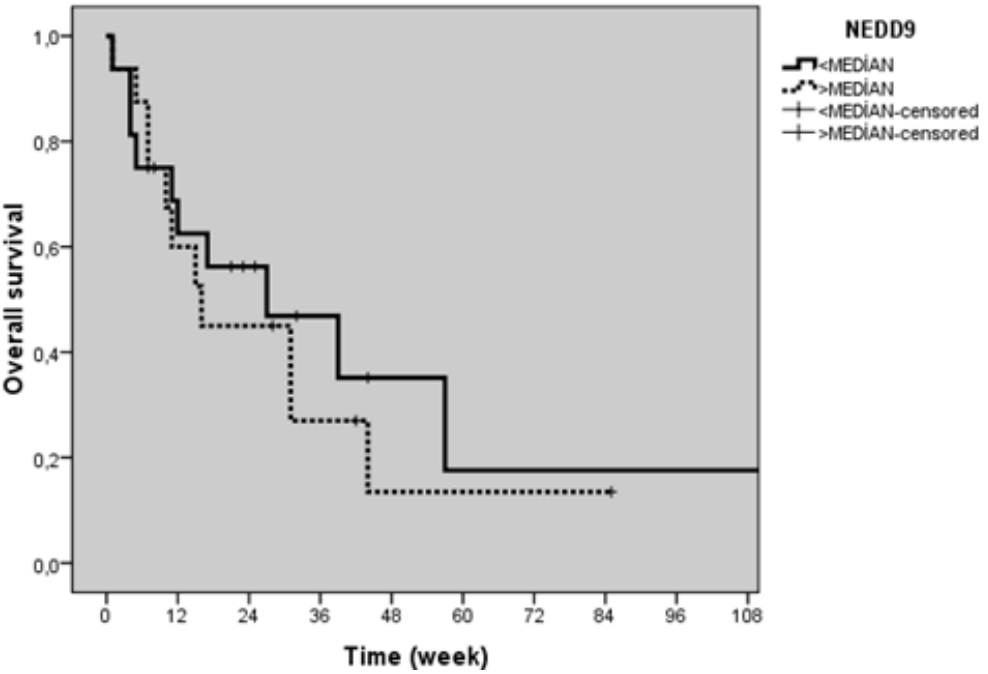

Figure 3. Overall survival curves in pancreatic cancer patients according to serum NEDD9 levels $(p=0.58)$. 


\section{Discussion}

Pancreatic cancer (PC) is a highly lethal malignancy. Extensive research is being conducted to identify novel diagnostic, predictive, and prognostic biomarkers for PC [18]. NEDD9 supports oncogenic signaling in a number of solid and hematologic tumors. Aurora A kinase (AURKA) is overexpressed in $96 \%$ of human cancers and is considered an independent marker of poor prognosis. NEDD9 depletion destabilizes AURKA and heightens the efficacy of Aurora A inhibitors and it has implications for treatment of metastatic solid tumors [19]. NEDD9 has been found to be diagnostic, prognostic, and predictive in different kinds of tumor types [12,20-22].

Little is known about the role of NEDD9 in PC but available data suggest elevated NEDD9 levels have been found in PC patients and it can have a prognostic role [15-18,20]. High levels of expression of NEDD9 were significantly correlated with clinical staging, lymph node metastasis, and histological differentiation in PC patients [15]. NEDD9 expression was not statistically correlated with tumor stage and grade, gender, or patient survival in another study done by Radulović et al. [18].

Novel therapeutic agents are being investigated in PC. Not only the tumor cells but also the stroma is very important in PC. Immunotherapeutic options are limited and we are still using various kinds of chemotherapies. MicroRNA-145 suppresses cell proliferation, invasion and migration in PC cells by targeting NEDD9 [16]. NEDD9 increases the invasiveness of solid tumors such as gastric cancer, ovarian cancer, and glioblastoma $[14,20,23]$. There is growing evidence that NEDD9 is itself nononcogenic but changes in expression of NEDD9 (most commonly elevation of expression) are common features of tumors, and directly impact tumor aggressiveness, metastasis, and response to at least some targeted agents inhibiting NEDD9-interacting proteins. These data strongly support the relevance of further development of NEDD9 as a biomarker for therapeutic resistance [24].

\section{Conclusions}

According to these data, in our study, we found out that NEDD9 can be used as a diagnostic marker for patients with PC but it has no prognostic role. The limitation of our study is the small sample size.

Author Contributions: Conceptualization, S.K. and C.U.A; Methodology, C.U.A; Software, M.K.; Validation, M.S.; Formal Analysis, M.C.; Investigation, F.T.; Resources, S.T.O.; Data Curation, M.K.; Writing-Original Draft Preparation, C.U.A.; Writing-Review \& Editing, C.U.A. and S.K.; Visualization, M.S.; Supervision, F.T.; Project Administration, M.C. and S.T.O.; Funding Acquisition, S.K.

Funding: This research received no external funding.

Acknowledgments: None.

Conflicts of Interest: The authors declare no conflict of interest.

\section{References}

1. Niederhuber, J.E.; Brennan, M.F.; Menck, H.R. The National Cancer Data Base report on pancreatic cancer. Cancer 1995, 76, 1671-1677. [CrossRef]

2. Siegel, R.L.; Miller, K.D.; Jemal, A. Cancer statistics, 2018. CA Cancer J. Clin. 2018, 68, 7-30. [CrossRef] [PubMed]

3. Jimenez, R.E.; Warshaw, A.L.; Z'graggen, K.; Hartwig, W.; Taylor, D.Z.; Compton, C.C.; Fernández-del Castillo, C. Sequential accumulation of K-ras mutations and p53 overexpression in the progression of pancreatic mucinous cystic neoplasms to malignancy. Ann. Surg. 1999, 230, 501-509. [CrossRef] [PubMed]

4. Wu, J.; Jiao, Y.; Dal Molin, M.; Maitra, A.; de Wilde, R.F.; Wood, L.D.; Eshleman, J.R.; Goggins, M.G.; Wolfgang, C.L.; Canto, M.I.; et al. Whole-exome sequencing of neoplastic cysts of the pancreas reveals recurrent mutations in components of ubiquitin-dependent pathways. Proc. Natl. Acad. Sci. USA 2011, 108, 21188-21193. [CrossRef] [PubMed] 
5. Dreyer, C.; Afchain, P.; Trouilloud, I.; André, T. New molecular classification of colorectal cancer, pancreatic cancer and stomach cancer: Towards “à la carte" treatment? Bull. Cancer 2016, 103, 643-650. [CrossRef] [PubMed]

6. Phallen, J.; Sausen, M.; Adleff, V.; Leal, A.; Hruban, C.; White, J.; Anagnostou, V.; Fiksel, J.; Cristiano, S.; Papp, E.; et al. Direct detection of early-stage cancers using circulating tumor DNA. Sci. Transl. Med. 2017, 9, eaan2415. [CrossRef] [PubMed]

7. Cohen, J.D.; Javed, A.A.; Thoburn, C.; Wong, F.; Tie, J.; Gibbs, P.; Schmidt, C.M.; Yip-Schneider, M.T.; Allen, P.J.; Schattner, M.; et al. Combined circulating tumor DNA and protein biomarker-based liquid biopsy for the earlier detection of pancreatic cancers. Proc. Natl. Acad. Sci. USA 2017, 114, 10202-10207. [CrossRef] [PubMed]

8. Kumar, S.; Tomooka, Y.; Noda, M. Identification of a set of genes with developmentally down-regulated expression in the mouse brain. Biochem. Biophys. Res. Commun. 1992, 185, 1155-1161. [CrossRef]

9. Minn, A.J.; Gupta, G.P.; Siegel, P.M.; Bos, P.D.; Shu, W.; Giri, D.D.; Viale, A.; Olshen, A.B.; Gerald, W.L.; Massagué, J. Genes that mediate breast cancer metastasis to lung. Nature 2005, 436, 518-524. [CrossRef]

10. Natarajan, M.; Stewart, J.E.; Golemis, E.A.; Pugacheva, E.N.; Alexandropoulos, K.; Cox, B.D.; Wang, W.; Grammer, J.R.; Gladson, C.L. HEF1 is a necessary and specific downstream effector of FAK that promotes the migration of glioblastoma cells. Oncogene 2006, 25, 1721-1732. [CrossRef]

11. Kim, M.; Gans, J.D.; Nogueira, C.; Wang, A.; Paik, J.H.; Feng, B.; Brennan, C.; Hahn, W.C.; Cordon-Cardo, C.; Wagner, S.N.; et al. Comparative oncogenomics identifies NEDD9 as a melanoma metastasis gene. Cell 2006, 125, 1269-1281. [CrossRef] [PubMed]

12. Wang, J.; Wang, S.; Luan, Y.; Zhang, W.; Sun, C.; Cheng, G.; Li, K.; Xin, Q.; Lin, Z.; Qi, T.; et al. Overexpression of NEDD9 in renal cell carcinoma is associated with tumor migration and invasion. Oncol. Lett. 2017, 14, 8021-8027. [CrossRef] [PubMed]

13. Zhou, S.; Xu, M.; Shen, J.; Liu, X.; Chen, M.; Cai, X. Overexpression of NEDD9 promotes cell invasion and metastasis in hepatocellular carcinoma. Clin. Res. Hepatol. Gastroenterol. 2017, 41, 677-686. [CrossRef] [PubMed]

14. Karabulut, M.; Alis, H.; Afsar, C.U.; Karabulut, S.; Kocatas, A.; Oguz, H.; Aykan, N.F. Serum neural precursor cell-expressed, developmentally down regulated 9 (NEDD9) level may have a prognostic role in patients with gastric cancer. Biomed. Pharmacother. 2015, 73, 140-146. [CrossRef] [PubMed]

15. Xue, Y.Z.; Sheng, Y.Y.; Liu, Z.L.; Wei, Z.Q.; Cao, H.Y.; Wu, Y.M.; Lu, Y.F.; Yu, L.H.; Li, J.P.; Li, Z.S. Expression of NEDD9 in pancreatic ductal adenocarcinoma and its clinical significance. Tumour. Biol. 2013, 34, 895-899. [CrossRef] [PubMed]

16. Han, T.; Yi, X.P.; Liu, B.; Ke, M.J.; Li, Y.X. MicroRNA-145 suppresses cell proliferation, invasion and migration in pancreatic cancer cells by targeting NEDD9. Mol. Med. Rep. 2015, 11, 4115-4120. [CrossRef] [PubMed]

17. Zhou, R.T.; He, M.; Yu, Z.; Liang, Y.; Nie, Y.; Tai, S.; Teng, C.B. Baicalein inhibits pancreatic cancer cell proliferation and invasion via suppression of NEDD9 expression and its downstream Akt and ERK signaling pathways. Oncotarget 2017, 8, 56351-56363. [CrossRef]

18. Radulović, P.; Krušlin, B. Immunohistochemical expression of NEDD9, E-cadherin and $\gamma$-catenin and their prognostic significance in pancreatic ductal adenocarcinoma (PDAC). Bosn. J. Basic Med. Sci. 2018, 18, 246. [CrossRef]

19. Ice, R.J.; McLaughlin, S.L.; Livengood, R.H.; Culp, M.V.; Eddy, E.R.; Ivanov, A.V.; Pugacheva, E.N. NEDD9 depletion destabilizes Aurora A kinase and heightens the efficacy of Aurora A inhibitors: İmplications for treatment of metastatic solid tumors. Cancer Res. 2013, 73, 3168-3180. [CrossRef]

20. Gabbasov, R.; Xiao, F.; Howe, C.G.; Bickel, L.E.; O’Brien, S.W.; Benrubi, D.; Do, T.-V.; Zhou, Y.; Nicolas, E.; Cai, K.Q.; et al. NEDD9 promotes oncogenic signaling, a stem/mesenchymal gene signature, and aggressive ovarian cancer growth in mice. Oncogene 2018, 37, 4854-4870. [CrossRef]

21. El-Babouly, I.M.; Desoky, E.A.E.; El Sayed, D.; Ali, M.M.; Harb, O.A.; Ragab, A.; Sakr, A.M.; Fawzi, A.M.; Salama, N.M.; Samaha, I.I. The role of neural precursor cell-expressed developmentally down-regulated protein 9 in predicting bacillus Calmette-Guerin response in nonmuscle invasive bladder cancer. Urol. Oncol. 2018, 36, 242.e9-242.e14. [CrossRef] [PubMed]

22. Pallarès, V.; Hoyos, M.; Chillón, M.C.; Barragán, E.; Conde, M.I.P.; Llop, M.; Céspedes, M.V.; Nomdedeu, J.F.; Brunet, S.; Sanz, M.Á. NEDD9, an independent good prognostic factor in intermediate-risk acute myeloid leukemia patients. Oncotarget 2017, 8, 76003-76014. [CrossRef] [PubMed] 
23. Speranza, M.C.; Frattini, V.; Pisati, F.; Kapetis, D.; Porrati, P.; Eoli, M.; Pellegatta, S.; Finocchiaro, G. NEDD9, a novel target of miR-145, increases the invasiveness of glioblastoma. Oncotarget 2012, 3, 723-734. [CrossRef] [PubMed]

24. Shagisultanova, E.; Gaponova, A.V.; Gabbasov, R.; Nicolas, E.; Golemis, E.A. Preclinical and clinical studies of the NEDD9 scaffold protein in cancer and other diseases. Gene 2015, 567, 1-11. [CrossRef] [PubMed]

(c) 2018 by the authors. Licensee MDPI, Basel, Switzerland. This article is an open access article distributed under the terms and conditions of the Creative Commons Attribution (CC BY) license (http:/ / creativecommons.org/licenses/by/4.0/). 